To Cite: Karataş, N, 2021. Some Important Fruit Characteristics of Apricot (cv. Aprikoz) Accessions Grown in Kagizman District in Turkey. Journal of the Institute of Science and Technology, 11(2): 1176-1182.

\title{
Some Important Fruit Characteristics of Apricot (cv. Aprikoz) Accessions Grown in Kagizman District in Turkey
}

Neva KARATAŞ ${ }^{1 *}$

\begin{abstract}
With their rich nutrients, fantastic flavor and taste, excellent medicinal value and health care functions, apricot has been continuously well received by consumers as important horticultural crop. The fruit has a great market value as fresh and dried food commodity and has the highest market share of agricultural income. Aprikoz an important apricot cultivar in particularly grown in western part of Aras valley located in Eastern Anatolia in Turkey. With long growing period, different types of Aprikoz cultivar has been shown in field in terms of tree and fruit characteristics. This study aimed to determine of some important fruit characteristic of eight accession of Aprikoz cultivar grown in Kagizman district located in western part of Aras valley. The accessions were compared each other in terms of fruit weight, flesh/seed ratio, soluble solid content, titratable acidity, total antioxidant capacity and total phenolic content. The results revealed that accessions statistically highly differed from each other for all of the searched parameters. The accessions exhibited fruit weight, fruit flesh/seed ratio, soluble solid content and titratable acidity between $36.55-48.22 \mathrm{~g}, 8.67-13.33,19.12-22.83 \%$ and $1.27-2.02 \%$, respectively. Total antioxidant capacity varied from 4.17 to 6.37 mmol AA $1-1$ based on FRAP assay. The total phenolic contents ranged between 255 - $356 \mathrm{mg}$ GAE 1-1. The results can be the basis for the selection of suitable accessions for future breeding activities in apricot.
\end{abstract}

Keywords: Apricot, diversity, phytochemicals, breeding

${ }^{1}$ Neva KARATAŞ (Orcid ID: 0000-0003-4426-3761), Department of Nutrition and Dietetics, Faculty of Health Sciences, Ataturk University, Erzurum, Turkey,

* Corresponding Author: Neva KARATAŞ, e-mail: ngungor@atauni.edu.tr 


\section{INTRODUCTION}

Apricot (Prunus armeniaca L.) is among the stone fruits as peach, plum, sweet cherry, sour cherry etc. and was originated in China and the references of their culture go back to $3000 \mathrm{BC}$. From origin center, it was spread first to India later to Persia and Anatolia, finally arriving at Europe and North America. It is evident that it spread from Spain to America where it underwent acclimatization to tempered areas, mainly in California and along the river Mississippi (Lingdi and Bartholomew, 2003; Yilmaz and Gurcan, 2012; Gecer et al., 2020).

Currently, the countries that are closer to origin center of China such as Pakistan, Uzbekistan, Iran and Turkey are the main apricot producing countries. Worldwide 3900000 tons of apricot are produced per year and Turkey is the largest apricot producer in the world with 800000 tons production volume per year. Uzbekistan and Iran comes second and third place with 662000 and 306000 tons yearly production. The main producer in European continent is Spain, France and Greece but the amount of production per year is getting decreasing. Those countries produce 125000 tons, 110000 tons and 79 000 tons apricot per years, respectively (FAO, 2019).

Turkey is accepted second homeland of apricot (Prunus armeniaca L.) and the country leading both fresh and dried apricots in the world for a long time. In Turkey, several places are important for apricot production and those including Malatya-Elazig region, Aras Valley, Erzincan Plain, Cappadocia and Mut region (Akin et al., 2008; Ercisli, 2009).

Aras valley (Kars-Igdir region) is one of the important apricot cultivation areas of Turkey. The valley has the oldest apricot growing area in Turkey. This region, which has a suitable microclimate feature for fruit growing in the harsh continental climate area of the Eastern Anatolia Region, stands out in terms of some features, although it meets approximately $7 \%$ of the country's apricot production. Apricot trees in the valley has high yield per tree, high table quality, especially its being exported because of its aromatic properties, are its important advantages. Kagizman district provides almost all of the apricot production in Kars province. In the district, Aprikoz, Sekerpare and wild apricots are grown. Aprikoz, a table cultivar, has the highest plantation area and is mostly grown on the flat land, is marketed abroad and generates high income (Ates and Calikoglu, 2017).

The apricot trees have pale yellow or orange fruits with some red shades in the zone where they have been exposed to the sun. The pulp is not very juicy, it has fibre texture and farinaceous consistency when the fruit is mature. It is mainly consumed fresh, although it is also used to make some by-products like stewed fruit, jams, juices and dried apricots. The skin is downy and pulp has a pleasant firm texture (Ruiz et al., 2008).

The apricot fruit is characterized by the presence high carbohydrate and dietary fibre as well as low concentrations of fats (Leccese et al., 2011). Apricot fruits contain important amounts of essential minerals that include potassium, phosphorus, calcium, magnesium, iron and selenium (Munzuroglu et al., 2003; Ali et al., 2011). The vitamins found in apricot fruits are pro-vitamin A, vitamins C, K, E, thiamin (B1), riboflavin (B2), niacin (B3), pyridoxine (B6), folic acid (B9) and pantothenic acid. Apricot fruits contain malic and citric acid as major organic acids (Gurrieri et al., 2001).

Apricot fruits contain also important amounts of bioactive compounds and antioxidants, including vitamins, phenolic acids, carotenoids, and flavonoids. The fruit is a very rich $\beta$-carotene source (Hegedus et al., 2010; Sochor et al., 2010). $\beta$-carotene, the precursor of vitamin A, is necessary for the functions of epithelial tissue that surrounds the organs, eye health, bone and tooth development and endocrine glands. Vitamin A also plays an important role in growth and reproduction, and resistance of the body against infections (Selamoglu and Erdemli, 2017). 
Natural phenolic compounds continue to attract the interest of numerous scientists due to possible relations between their content in diet and lower incidence of cancer or cardiovascular diseases (Sochor et al. 2010). Determination of total antioxidant capacity is one of the ways of expressing the biological and nutritional value of fruits (Gazdik et al. 2008).

The aim of the study was to evaluate and compare the fruit morphological traits, biochemical content and antioxidant potential of eight accessions of cv. Aprikoz and thus to reveal the benefit potential of the accessions to use them for future breeding efforts on apricot.

\section{MATERIALS AND METHODS}

\section{Plant Material}

In this study eight Aprikoz accessions were sampled from Kagizman district in 2017. Fruit weight (g) and flesh/seed ratio of 40 randomly selected fruits of each Aprikoz accessions was measured. Soluble solid content (SSC), expressed as percentage (\%), was determined in the juice of each sample using a digital refractometer. Titratable acidity was determined by titrating $10 \mathrm{ml}$ of 1:10 diluted apricot pulp $(10 \mathrm{~g})$ with $0.1 \mathrm{M} \mathrm{NaOH}$. Antioxidant capacity was determined using the FRAP (Ferric Reducing Antioxidant Power) assay (Benzie and Strain, 1996). Absorbance was measured at $593 \mathrm{~nm}$ at 0 and 6 min. Ascorbic acid (AA) was used as control to obtain the standard curve and FRAP value was calculated relevant to the activity of AA and expressed as AA equivalents. Total phenolic content was measured using Folin-Ciocalteu's reagent according to the method of Singleton and Rossi (1965).

\section{Statistical Analysis}

All data were analyzed using SPSS software and procedures. Analysis of variance tables were constructed using the Least Significant Difference (LSD) method at $\mathrm{p}<0.05$.

\section{RESULTS AND DISCUSSION}

Differences were noted between apricot accessions belongs to Aprikoz cultivar for most of the evaluated physical and biochemical traits (Tables 1 and 2) shows that the elite accessions AP1, AP2, AP4, AP6 and AP7 presented fruits with weight $>40 \mathrm{~g}$, and fruits with lower weight were verified in the elite accessions AP3, AP5 and AP8, respectively (Table 1).

Table 1 shows fruit weight and flesh/seed ratio of eight Aprikoz accessions. There were statistically significant differences among accessions in terms of fruit weight and flesh/seed ratio at 0.05 statistical levels. The highest fruit weight was obtained from AP6 accession as $48.22 \mathrm{~g}$ and followed by AP2 accession as $45.23 \mathrm{~g}$ while the lowest fruit weight values was obtained in AP3 accession as 36.55 $\mathrm{g}$, respectively (Table 1).

Table 1. Fruit weight and flesh/seed ratio of eight Aprikoz accessions

\begin{tabular}{ccc}
\hline Accessions & Fruit weight $(\mathbf{g})$ & Flesh/seed ratio \\
\hline AP1 & $40.15 \mathrm{c}$ & $9.35 \mathrm{bc}$ \\
AP2 & $45.23 \mathrm{ab}$ & $11.18 \mathrm{~b}$ \\
AP3 & $36.55 \mathrm{~d}$ & $8.95 \mathrm{c}$ \\
AP4 & $44.55 \mathrm{~b}$ & $13.33 \mathrm{a}$ \\
AP5 & $38.18 \mathrm{~cd}$ & $9.78 \mathrm{bc}$ \\
AP6 & $48.22 \mathrm{a}$ & $11.87 \mathrm{~b}$ \\
AP7 & $41.40 \mathrm{bc}$ & $12.07 \mathrm{ab}$ \\
AP8 & $37.55 \mathrm{~cd}$ & $8.67 \mathrm{c}$ \\
\hline
\end{tabular}

There were significant $(P<0.05)$ differences among the different letters in the same lines 
The flesh/seed ratio is an important fruit characteristic for apricots. The eight accessions had fruit flesh/seed ratio between 8.67 (AP8) and 13.33 (AP4) (Table 1). The flesh seed ratio of the accessions was in descending order AP4 (13.33) >AP7 (12.07) > AP6 (11.87) > AP2 (11.18) > AP5 (9.78) > AP1 (9.35) > AP3 (8.95) > AP8 (8.67), respectively (Table 1).

Fruit weights were found between 36.55 - $48.22 \mathrm{~g}$ among 8 accessions in Aprikoz cultivar. In Turkey, standard national apricot cultivars have relatively small size fruits. Akin et al. (2008) also supported this idea and reported fruit weight between 21.16 - $38.24 \mathrm{~g}$ among the most important national apricot cultivars grown in Malatya region in Turkey. Yilmaz et al. (2012) reported that 92-23-02, Kayseri (PA), Hirmanli and Tekeler apricot genotypes in Turkey had very small fruits, 01-K-12, 31-K-03, 31K-04, Sakit-2, Sakit-4, Dortyol-1, Dortyol-4, 92-58-03, Kadioglu-12, Tevfik Yildirim, Akcadag Gunay, Sivas (PA), Kurukabuk, Proyma had small fruits. Asma and Ozturk (2005) reported that 128 Turkish apricot genotypes placed in the Iran-Caucasian ecogeographical group generally had low fruit weight. The authors reported that the fruit weight of only 7 apricot cultivars was over $50 \mathrm{~g}$, and the others had lower fruit weights. The reason could be all Turkish national apricot cultivars obtained from wild populations by using selection method. Gulcan et al. (2006) reported that apricot cultivars had diverse fruit weight and Agerik had the highest fruit weight and Hacikiz had lowest.

The flesh/seed ratio is an important fruit characteristic for apricots (Ercisli, 2009). The eight accessions had fruit flesh/seed ratio 8.67 (AP8) and 13.33 (AP4) (Table 1). Yilmaz et al. (2012) reported flesh/seed ratio on Levent and Ozal apricot cultivars grown in Malatya between 7.90 - 10.38 and 10.94 - 13.58 according to years. Previously the flesh/seed ratios of the foreign apricot cultivars grown in Turkey varied between 8.9 and 21.8 (Polat and Yilmaz, 1988; Polat et al., 2004).

Table 2 shows SSC, titratable acidity, total antioxidant capacity and total phenolic content of eight Aprikoz accessions. As indicated in Table 2 all searched above parameters revealed statistically significant differences $(\mathrm{p}<0.05)$.

Table 2. Soluble Solid Content (SSC), Titratable Acidity, Antioxidant Activity (FRAP assay) and Total Phenolic Content (TPC) of eight Aprikoz accessions

\begin{tabular}{|c|c|c|c|c|}
\hline Accessions & $\begin{array}{l}\text { SSC } \\
(\%)\end{array}$ & $\begin{array}{c}\text { Titratable acidity } \\
(\%)\end{array}$ & $\begin{array}{c}\text { Total Antioxidant Capacity } \\
(\text { mmol AA I l-1) }\end{array}$ & $\begin{array}{l}\text { Total phenolic conten } \\
\left.\text { (mg GAE100 g } \mathrm{g}^{-1} \mathrm{FW}\right)\end{array}$ \\
\hline AP1 & $20.44 b c$ & $1.27 \mathrm{c}$ & $5.44 \mathrm{bc}$ & $327 \mathrm{ab}$ \\
\hline AP2 & $21.67 \mathrm{ab}$ & $1.87 \mathrm{ab}$ & $5.07 \mathrm{c}$ & $302 b$ \\
\hline AP3 & $19.12 \mathrm{c}$ & $1.44 b c$ & $6.37 \mathrm{a}$ & $356 a$ \\
\hline AP4 & $22.14 \mathrm{ab}$ & $2.02 \mathrm{a}$ & $4.87 \mathrm{~cd}$ & $293 b c$ \\
\hline AP5 & $19.56 b c$ & $1.57 \mathrm{~b}$ & $6.06 \mathrm{ab}$ & $310 \mathrm{ab}$ \\
\hline AP6 & $22.83 a$ & $1.90 \mathrm{ab}$ & $4.17 \mathrm{e}$ & $255 \mathrm{c}$ \\
\hline AP7 & $21.02 \mathrm{~b}$ & $1.63 b$ & $5.87 \mathrm{~b}$ & 330ab \\
\hline AP8 & $20.07 \mathrm{bc}$ & $1.44 \mathrm{bc}$ & $4.50 \mathrm{~d}$ & $278 \mathrm{bc}$ \\
\hline
\end{tabular}

There were significant $(P<0.05)$ differences among the different letters in the same lines

SSC content and titratable acidity of accessions were found in range of $19.12 \%$ (AP3) and $22.83 \%$ (AP6) and $1.27 \%$ (AP1) and 2.02\% (AP4), respectively (Table 2). The SSC ratios of the accessions were in descending order AP6 (22.83) > AP4 (22.14) > AP2 (21.67) > AP7 (21.02) > AP1 (20.44) > AP8 (20.07) > AP5 (19.56) > AP3 (19.12), respectively (Table 2).

As showed in Table 2, the accessions were evaluated for both total antioxidant capacity (FRAP values) and total phenolic content (TPC) and they differed each other statistically for both parameters. The total antioxidant capacity determined as FRAP values and the highest value were determined in AP3 genotype as $6.76 \mathrm{mmol}$ AA 1-1 and followed by AP5 as 6.06 mmol AA 1-1, AP7 as 5.87 mmol AA 1-1, 
respectively. The lowest antioxidant capacity was obtained from AP6 genotype as 4.17 mmol AA 1-1 (Table 2). The total phenolic contents (TPC) ranged between $255 \mathrm{mg}$ GAE 1-1 (AP6 genotype) to 356 mg GAE 1-1 (AP3 genotype), respectively (Table 2). The highest TPC content were found in AP3 as 356 mg GAE 1-1 and followed by AP7 (330 mg GAE 1-1), AP1 (327 mg GAE 1-1), AP5 (310 mg GAE 1-1), AP2 (302 mg GAE 1-1), AP4 (293 mg GAE 1-1), AP8 (278 mg GAE 1-1) and AP6 (255 mg GAE 1$1)$, respectively.

SSC content and titratable acidity of accessions were found in range of $19.12 \%$ (AP3) and $22.83 \%$ (AP6) and $1.27 \%$ (AP1) and 2.02\% (AP4), respectively (Table 2). Previous studies showed that there was a great diversity among apricot cultivars in terms of SSC and titratable acidity. Akin et al. (2008) reported that the most important Turkish apricot cultivars had SSC and titratable acidity between 10.20 and $23.65 \%$ and 0.08 and $1.00 \%$, respectively. Gulcan et al. (2006) reported that Abuzer Gülen had the highest acidity value and Ziraat Okulu had the lowest SSC among national apricot cultivars in Turkey. SSC or sugar content in fruits represents from $10-20 \%$ of the fruit's fresh weight and increases as fruit matures to produce a less acidic, sweeter fruit. During the ripening process stone fruit acids are degraded, the sugar content increases, and the sugar/acid ratio reaches a higher value. A high level of acidity common in under - ripe fruit - makes the fruit taste sour. Conversely, over-ripe fruits have very low levels of fruit acid and therefore lack characteristic flavor. It is important that the grower aims to produce an acceptable balance of SSC and fruit acidity. The SSC/acid ratio is a key characteristic determining the taste, texture and feel of fruit segments. It contributes towards giving many fruits their characteristic flavor. It is also an indicator of commercial and sensory ripeness (Kelebek and Selli, 2011; Ronggao et al., 2015). These SSC results of eight Aprikoz accessions are claimed that enough genetic diversity exists in Aprikoz accessions to mitigate the adverse effects of climate warming on fruit quality.

The total antioxidant capacity determined as FRAP values were between 5.87 - 6.76 mmol AA 11. The total phenolic contents (TPC) ranged between $255 \mathrm{mg}$ GAE-1 (AP6 genotype) to $356 \mathrm{mg}$ GAE 1-1 (AP3 genotype), respectively (Table 2). Previously total antioxidant capacity of a wide number of apricot cultivars was found between 0.47 - 14.00 mmol 1-1 (Hegedus et al. 2010). Same study also indicated wide differences among TPC (Total phenolic content) among same apricot cultivars between 120-890 mg mg GAE 1-1 Results of this study indicating that Aprikoz accessions rich for antioxidant capacity and phenolic contents as well. In fact, apricot fruits have been considered as having enhanced functional properties for a long time and this study is also confirm of this idea.

Previous studies indicated that as with other stone fruits, several factors were shown to influence the fruit antioxidant capacity, including geographic region, maturity stage, and length of the fruit development period (Dragovic-Uzelac et al. 2007; Drogoudi et al. 2008; Serrano et al. 2009). However, genotype proved to be the most important factor influencing the fruits' redox parameters and antioxidant contents (Sass-Kiss et al. 2005; Hegedus et al. 2010).

\section{CONCLUSION}

As a conclusion, we found significant differences between the accessions for most of the tested physical and biochemical characteristics of fruits in this study. Of the 8 accessions, AP1 genotype presented with the highest fruit weight, being the third highest total phenolic content. The study population showed genetic variability, allowing new selection and recombination cycles to gain pulp yield, bioactive content and fruit weight. The accessions AP1 and AP3 accessions were reported to be the most divergent among the other accessions. These 2 elite accessions should; therefore, be considered as parent plants in further studies of general and specific combining ability with other selected breeds for productivity within the apricot-breeding program. 


\section{Conflict of Interest}

I declare that there is no conflict of interest during the planning, execution and writing of the article.

\section{Author's Contilbutions}

I hereby declare that the planning, execution and writing of the article was done by me as the sole author of the article.

\section{REFERENCES}

Akin EB, Karabulut I, Topcu A, 2008. Some compositional properties of main Malatya apricot (Prunus armeniaca L.) varieties. Food Chemistry, 107: 939-948.

Ali S, Masud T, Abbasi KS, 2011. Physico-chemical characteristics of apricot (Prunus armeniaca L.) grown in Northern Areas of Pakistan. Scientia Horticulture, 130 (2): 386-392.

Asma BM, Ozturk K, 2005. Analysis of morphological, pomological and yield characteristics of some apricot germplasm in Turkey. Genetic Resources and Crop Evolution, 52: 305-313.

Atis E, Celikoglu S, 2017. Apricot producing in Kagizman district and its contribution to the economy of territory. Marmara Geographical Journal, 36: 191-205.

Benzie, I.F.F., Strain, J.J., 1996. The ferric reducing ability of plasma (FRAP) as a measure of "antioxidant power": the FRAP assay. Analytical Biochemistry, 239: 70-76.

Dragovic-Uzelac, V., Levaj, B., Mrkic, V., Bursac, D., Boras, M., 2007. The content of polyphenols and carotenoids in three apricot cultivars depending on stage of maturity and geographical region. Food Chemistry, 102: 966-975.

Drogoudi, P.D., Vemmos, S., Pantelidis, G., Petri, E., Tzoutzoukou, C., Karayiannis, I., 2008. Physical characters and antioxidant, sugar, and mineral nutrient contents in fruit from 29 apricot (Prunus armeniaca L.) cultivars and hybrids. Journal of Agriculture and Food Chemistry, 56: 1075410760.

Ercisli S, 2009. Apricot culture in Turkey. 2009. Scientific Research and Essays, 4:715-719.

FAO (2019). Crop Statistical database.

Gazdik Z, Reznicek V, Adam V, Zitka O, Jurikova T, Krska B, Matuskovic J, Plsek J, Saloun J, Horna A, Kizek R, 2008. Use of liquid chromatography with electrochemical detection for the determination of antioxidants in less common fruits. Molecules, 13: 2823-2836.

Gecer MK; Kan T, Gundogdu M, Ercisli S, Ilhan G, Sagbas HI (2020). Physicochemical characteristics of wild and cultivated apricots (Prunus armeniaca L.) from Aras valley in Turkey. Genetic Resources and Crop Evolution, 67: 935-945.

Gulcan R, Misırlı A, Sağlam H, Yorgancioğlu U, Erkan S, Gümüs M, Ölmez HA, Derin K, Paydaş S, Eti S, Demir T, (2006) Properties of Turkish apricot landraces. Acta Horticulturae, 701: 191-198.

Gurrieri F, Audergon JM, Albagnac G, Reich M, 2001. Soluble sugars and carboxylic acids in ripe apricot fruit iș parameters for distinguishing different cultivars. Euphytica, 117:183-189.

Hegedus A, Engel R, Abranko L, Balogh E, Blazovics A, Herman R, Halasz J, Ercisli S, Pedryc A, Stefanovits-Banyai E, 2010. Antioxidant and antiradical capacities in apricot (Prunus armeniaca L.) fruits: Variation from genotypes, years, and analytical methods. Journal of Food Science, 75 (9):C722-C730.

Kelebek H, Selli S, 2011. Determination of volatile, phenolic, organic acid and sugar components in a Turkish cv. Dortyol (Citrus sinensis L. Osbeck) orange juice. Journal of the Science of Food and Agriculture, 9: 1855-1862. 
Leccese A, Viti R, Bartolini S, 2011. The effect of solvent extraction on antioxidant properties of apricot

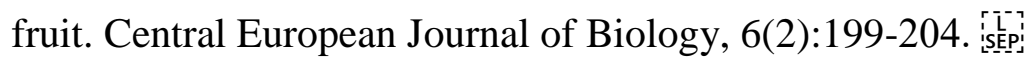

Lingdi L, Bartholomew B, 2003. Armeniaca. In: Flora of China (eds Wu CY, Raven PH), pp. 396-401. Science Press and Missouri Botanical Garden Press, Beijing.

Munzuroglu O, Karatas F, Geckil H, 2003. The vitamin and selenium contents of apricot fruit of different varieties cultivated in different geographical regions. Food Chemistry, 83:205-212. sichp:

Polat AA, Yilmaz M, 1988. Investigations on the adaptations of some native and foreign apricot cultivars to Adana ecological conditions. Journal of Science and Engineering, 2: 127-146.

Polat AA, Durgac C, Kamiloglu O, Caliskan O, 2004. Investigation on the adaptation of some low-chill apricot cultivars to Kirikhan (Turkey) ecological conditions. Acta Hortuculturae, 636:395-400.

Ronggao G, Wei Y, Zhihui W, Mingan L, Guolu L, 2015. Study on the sugar-acid ratio and relevant metabolizing enzyme activities in navel orange fruits from different eco-regions. Revista Brasileria de Fruticultura, 37:835-844.

Ruiz D, Egea J, Tomas-Barberan FA, Gil MI, 2005. Carotenoids from new apricot (Prunus armeniaca L.) varieties and their relationship with flesh and skin color. Journal of Agricultural and Food Chemistry, 53: 6368-6374.

Sass-Kiss A, Kiss J, Milotay P, Kerek MM, Toth-Markus M. 2005. Differences in anthocyanin and carotenoid content of fruits and vegetables. Food Research International, 38: 1023-1029.

Selamoglu Z, Erdemli ME, 2017. The significance of apricot in human health and nutrition. Biochemistry \& Molecular Biology Journal, 3:2??

Serrano, M., Diaz-Mula, H.M., Zapata, P.J., Castillo, S., Guillen, F., Martinez-Romero, D., Valverde, J.M., Valero, D., 2009. Maturity stage at harvest determines the fruit quality and antioxidant potential after storage of sweet cherry cultivars. Journal of Agriculture and Food Chemistry, 57: 3240-3246.

Singleton, V.L., Rossi, J.A., 1965. Colorimetry of total phenolics with phosphomolybdicphosphotungstic acid reagents. American Journal Enology and Viticulture, 16:144-158.

Sochor, J., Zitka, O., Skutkova, H., Pavlik, D., Babula, P., Krska, B., Horna, A., Adam, V., Provaznik, I., Kizek, R. (2010). Content of phenolic compounds and antioxidant capacity in fruits of apricot genotypes. Molecules, 15(9):6285-6305.

Yilmaz, K.U., Paydas Kargi, S., Kafkas, S., 2010. Morphological diversity of the Turkish apricot (Prunus armeniaca L.) germplasm in the Irano-Caucasian ecogeographical group. Turkish Journal of Agriculture and Forestry, 36:688-694.

Yilmaz KU, Gurcan K, 2012. Genetic diversity in apricot. In: Genetic Diversity in Plants (ed. Caliskan M), pp. 249-270. InTech Europe, Rijeka, Croatia. ISBN: 978-953-51-0185-7. http://www.intechopen.com/books/geneticdiversity-in-plants/genetic-diversity-in-apricot. 